\title{
KEGIATAN MANAJERIAL DALAM PEMBUDAYAAN HIDUP BERSIH DAN SEHAT DI TAMAN PENITIPAN ANAK RA DARUSSALAM KROYA CILACAP
}

\author{
Novan Ardy Wiyani \\ IAIN Purwokerto \\ Email: fenomenajiwa@gmail.com
}

\begin{abstract}
ABSTRAK
Penelitian ini bertujuan untuk mendeskripsikan kegiatan manajerial dalam pembudayaan hidup bersih dan sehat di TPA RA Darussalam Kroya. Penelitian ini menggunakan pendekatan kualitatif dan jenis penelitian fenomenologi. Data dikumpulkan menggunakan teknik wawancara, observasi, dan dokumentasi kemudian dianalisis menggunakan teknik analisis data Model Miles and Huberman. Hasil menunjukkan bahwa pembudayaan hidup bersih dan sehat dilakukan dengan berbagai kegiatan pembiasaan yang bersifat religius. Kegiatan manajerial di TPA pun lebih difokuskan untuk membudayakan hidup bersih dan sehat. Ini dilakukan agar berbagai kegiatan pembiasaan religius untuk membudayakan hidup bersih dan sehat dapat berlangsung secara efektif dan efisien. Ada empat kegiatan manajerial yang dilakukan. Pertama, perencanaan kegiatan pembiasaan religius untuk menciptakan budaya hidup bersih dan sehat. Kedua, pengorganisasian kegiatan pembiasaan religius untuk menciptakan budaya hidup bersih dan sehat. Ketiga, pelaksanaan kegiatan pembiasaan religius untuk menciptakan budaya hidup bersih dan sehat. Keempat, pengawasan kegiatan pembiasaan religius untuk menciptakan budaya hidup bersih dan sehat. Empat kegiatan manajerial tersbeut dapat dilakukan dengan baik karena Kepala TPA RA Darussalam Kroya mampu memimpin menggunakan gaya kepemimpinan demokratis.
\end{abstract}

Kata kunci: Bersih, Manajerial, Pembiasaan, Pembudayaan, Sehat.

\section{ABSTRACT}

This research is intended to describe managerial activities in the culture of clean and healthy living in TPA RA Darussalam Kroya. This study uses a qualitative approach and type of phenomenological research. Data were collected using interview, observation and documentation techniques and then analyzed using the Miles and Huberman Model data analysis technique. The results showed that the culture of clean and healthy living was carried out with various religious habituation activities. Managerial activities at the TPA are also more focused on developing clean and healthy living. This is done so that various religious habituation activities to civilize clean and healthy living can take place effectively 
and efficiently. There are four managerial activities carried out. First, the planning of religious habituation activities to create a culture of clean and healthy living. Second, organizing religious habituation activities to create a culture of clean and healthy living. Third, the implementation of religious habituation activities to create a culture of clean and healthy living. Fourth, supervision of religious habituation activities to create a culture of clean and healthy living. The four managerial activities can be carried out well because the head of TPA RA Darussalam Kroya is able to lead using a democratic leadership style.

Key Words: Clean, Managerial, Habituation, Acculturation, Healthy.

\section{PENDAHULUAN}

Kunci keberhasilan pemerintah dalam membangun negara adalah ada pada keberhasilan pemerintah dan masyarakat dalam menyelenggarakan layanan pendidikan dari jenjang Pendidikan Anak Usia Dini (PAUD) hingga jenjang Pendidikan Tinggi. Ini karena layanan pendidikan dapat berkontribusi terhadap pembentukan sumber daya manusia (SDM) yang cerdas, baik cerdas dari sisi intelektual maupun cerdas dari sisi emosional dan spiritual. Kecerdasan emosional dan spiritual atau ESQ (Emotional and Spiritual Quotient) pada diri anak didik pada dasarnya mencerminkan karakternya. Karakter anak didik menjadi sesuatu yang pertama dan utama dibentuk serta dikembangkan dalam layanan pendidikan.

Pada saat ini pemerintah begitu fokus dalam menyelenggarakan layanan pendidikan yang mengarah pada pembentukan karakter anak didik. Kepemilikan karakter yang baik pada anak didik akan sangat bermanfaat bagi dirinya dan bagi sesamanya (Erfantini dkk., 2019). Layanan pendidikan pun dipandang oleh banyak pakar edukasi sebagai salah satu sarana yang tepat untuk mengatasi lemahnya karakter masyarakat saat ini (Sulastri \& Fahmi, 2019).

Pembentukan karakter pada anak didik akan sangat tepat dilakukan ketika mereka belajar pada jenjang PAUD (Mulyasa, 2017). Anak usia dini merupakan individu yang baru lahir (usia 0 tahun) hingga berusia 6 tahun. Pada masa ini anak berada di masa keemasan (golden age). Pada masa ini optimalnya tumbuh kembang anak akan menentukan kecerdasannya di masa depannya. Usia dini pun menjadi masa yang sangat menentukan pembentukan karakter anak (Pamungkas dkk., 2018).

Pembentukan karakter pada anak usia dini dapat dilakukan melalui berbagai strategi. Strategi tersebut dapat diterapkan oleh setiap lembaga PAUD dengan memperhatikan progress tumbuh-kembang anak, sarana dan prasarana yang dimiliki, potensi guru, serta budaya di sekitar anak. Karakter pada anak dapat diperkuat melalui kegiatan pembudayaan perilaku positif (Tanto dkk., 2019). Ini karena budaya memiliki hubungan yang erat dengan cara berpikir pada seseorang, perasaan seseorang, dan perilaku seseorang (Mukhlis \& Mbelo, 2019).

Pembudayaan perilaku positif pada anak dapat dilakukan melalui kegiatan pembiasaan sehari-hari di lembaga PAUD dan di lingkungan keluarga. Pembiasaan merupakan salah satu strategi yang tepat digunakan untuk membentuk karakter anak karena anak terlibat langsung untuk berbuat baik di 
dalamnya (Supiana, Hermawan, \& Wahyuni, 2019). Keterlibatan pada anak dalam berbuat baik kemudian akan memunculkan kesadaran dan komitmen untuk selalu berbuat baik (Prayoga, 2019). Kepemilikan kesadaran dan komitmen pada diri anak sangat dibutuhkan dalam membudayakan hidup bersih dan sehat (Yufiarti dkk., 2019). Guru di lembaga PAUD memiliki peran yang strategis dalam upaya pembudayaan perilaku positif pada anak usia dini. Anak pun pada dasarnya membutuhkan nilai budaya sebagai sistem pengetahuan akan kebaikan sebagai media untuk melakukan imitasi. Itulah sebab pembudayaan perilaku positif tidak bisa dilepaskan dengan pemberian keteladanan oleh guru, orang tua, dan orang dewasa lainnya (Prahesti dkk., 2019).

Deskripsi tentang budaya perilaku positif membuat anak memiliki pengetahuan tentang kebaikan-kebaikan. Hal itu dapat dijadikan sebagai panduan bagi anak dalam melakukan penyesuaian diri ketika berada di lingkungan masyarakatnya serta di lembaga PAUD. Kemudian melalui bantuan guru, anak akan mampu mengendalikan munculnya emosi negatif yang bisa memunculkan perilaku negatif (Santoso \& Sutama, 2019). Jadi upaya membentuk karakter pada anak tidak hanya dilakukan melalui upaya pemberian pengetahuan tentang kebaikan, tetapi juga membiasakan anak untuk melakukan kebaikan-kebaikan dalam kehidupannya sehari-hari (Iswantiningtyas \& Wulansari, 2018). Hal itu telah dilakukan oleh Taman Penitipan Anak (TPA) RA Darussalam Kroya. Para guru sedang intens melakukan upaya pembudayaan perilaku positif melalui berbagai kegiatan pembiasaan. Pembudayaan perilaku positif yang ditekankan untuk dibentuk adalah budaya hidup bersih dan sehat.

Pada jenjang PAUD perilaku hidup bersih dan sehat menjadi program kegiatan pembiasaan yang dilakukan oleh anak usia dini. Ketika hidup bersih dan sehat telah menjadi kebiasaan maka akan muncul dan berkembang budaya hidup bersih dan sehat. Pada dasarnya tujuan dari pembudayaan hidup bersih dan sehat adalah untuk mengenali problem dan tingkat kesehatan anak serta untuk memberikan bekal kemampuan kepada anak untuk mengatasi, memelihara, meningkatkan dan melindungi kesehatannya sendiri (Margowati \& Astuti, 2017)

Ada tiga penelitian yang mengkaji tentang pembudayaan hidup bersih dan sehat pada anak usia dini. Pertama, penelitian Heny Wulandari yang berjudul "Pelaksanaan Pendidikan Kesehatan Perilaku Hidup Bersih dan Sehat pada Anak Usia Dini di TK ABA Tegalsari Yogyakarta". Pendidikan kesehatan perilaku hidup bersih dan sehat dilaksanakan dengan metode bercerita, pembiasaan, demonstrasi, bercakap-cakap, dan bernyanyi. Materi pendidikan kesehatan perilaku hidup bersih dan sehat disampaikan pada kegiatan cuci tangan, membuang sampah, menggosok gigi, buang air kecil dan buang air besar, memotong kuku, menyikat sepatu, dan membersihkan pakaian (Wulandari, 2011)

Kedua, penelitian Nurul Ana, Muhamad Ali dan Desni Yuniarni yang berjudul "Pembiasaan Perilaku Hidup Bersih Anak Usia Dini di PAUD Melati Jaya Jungkat Kecamatan Siantan". Hasil penelitian menunjukkan bahwa pembiasaan perilaku hidup bersih dan sehat dilakukan pada kegiatan kebersihan badan, kebersihan pakaian, dan kebersihan lingkungan sekolah. Kegiatan pembiasaan dilakukan secara individual dan kelompok menggunakan metode praktik 
langsung, bercakap-cakap, tanya jawab, demonstrasi dan keteladanan (Ana dkk., 2016).

Ketiga, penelitian Magdalena Chori Rahmawati dan Naomi Dias Laksita Dewi yang berjudul "Penanaman Perilaku Hidup Bersih dan Sehat di PAUD Atmabrata, Cilincing, Jakarta". Penanaman perilaku hidup bersih dilakukan dengan membiasakan anak untuk mencuci tangan dan makan makanan yang sehat. Anak memiliki kemampuan untuk mencuci tangan dan memakan makanan yang sehat ketika didampingi oleh gurunya (Rahmawati \& Dewi, 2019)

Penelitian penulis dengan ketiga penelitian di atas sama-sama mengkaji tentang budaya hidup bersih dan sehat. Perbedaannya dengan penelitian penulis ada dalam tiga hal. Pertama, jika penelitian pertama fokus pada pembudayaan hidup bersih dan sehat dengan pemberian materi dengan metode pembiasaan, maka penelitian penulis fokus pada kegiatan manajemen yang dilakukan dalam pembudayaan hidup bersih dan sehat. Kedua, jika penelitian kedua fokus pada pembudayaan hidup bersih dan sehat dengan membiasakan anak untuk melakukan kebersihan badan, pakaian dan lingkungan maka penelitian penulis fokus pada pembudayaan hidup bersih dengan melakukan kegiatan bersuci dan beribadah. Ketiga, jika penelitian ketiga membudayakan hidup bersih dan sehat dengan melakukan pendampingan, maka penelitian penulis memfokuskan penelitian pada upaya pembudayaan hidup bersih dan sehat dari sisi kegiatan manajerialnya. Kegiatan manajerial tersebut meliputi perencanaan, pengorganisasian, pelaksanaan, dan pengawasan (Farhani, 2019). Keempat, kegiatan manajerial tersebut disebut juga dengan istilah fungsi manajemen (Saajidah, 2019). Jadi penelitian penulis ditujukan untuk mendeskripsikan kegiatan manajerial dalam pembudayaan hidup bersih dan sehat di TPA RA Darussalam Kroya Cilacap. Hasil penelitian ini dapat dijadikan sebagai panduan bagi lembaga PAUD lainnya dalam melakukan kegiatan perencanaan, pengorganisasian, pelaksanaan dan pengawasan dalam membudayakan anak usia dini untuk hidup bersih dan sehat.

\section{METODE}

Penelitian ini menggunakan pendekatan kualitatif karena data yang tersaji dalam tulisan ini berupa deskripsi kata-kata maupun kalimat. Sedangkan jenis penelitian yang digunakan adalah penelitian fenomenologi. Penelitian fenomenologi dipilih karena penulis melakukan kajian pada objek yang memiliki keunikan jika dibandingkan dengan objek yang lain. Objek dalam penelitian ini adalah TPA RA Darussalam Kroya yang beralamatkan di Jalan Pangrango Nomor 56A Kroya.

Sumber data dalam penelitian ini antara lain kepala TPA, guru TPA, anak didik, dan wali murid. Data pada penelitian ini dikumpulkan menggunakan teknik wawancara, observasi dan dokumentasi. Data yang telah terkumpul kemudian diuji kevalidannya dengan teknik triangulasi teknik pengumpulan data. Penulis melakukan crosscheck data dengan mempertemukan data hasil wawancara, observasi dan dokumentasi secara simultan (Sugiyono, 2015). Kemudian data dianalisis menggunakan teknik analisis data model Miles and Huberman dengan melakukan tiga tahapan, yaitu reduksi data, penyajian data, dan verifikasi (Moleong, 2018). 


\section{HASIL DAN PEMBAHASAN}

Taman Penitipan Anak (TPA) RA Darussalam Kroya didirikan pada tahun 2012 untuk menampung keinginan dan kebutuhan wali murid di RA Darussalam Kroya. Wali murid menginginkan agar anak-anak mereka dititipkan di RA lebih lama lagi, dari pagi jam 08.00 hingga sore jam 15.00. Ini karena sebagian besar wali murid disibukkan oleh aktivitas kerjanya. Selain itu pihak manajemen RA Darussalam juga berinisiatif untuk menyelenggarakan layanan TPA sebagai respons mereka terhadap semakin ketatnya persaingan antar lembaga PAUD di Kroya. RA Darussalam Kroya pun menjadi satu-satunya lembaga PAUD di bawah naungan Kementrian Agama yang mampu menyelenggarakan layanan TPA yang secara kelembagaan berada di bawah naungan Kementrian Pendidikan dan Kebudayaan di kecamatan Kroya.

TPA RA Darussalam Kroya berbeda dengan TPA lainnya di kecamatan Kroya. Pihak manajemen memfokuskan berbagai kegiatan pembiasaan di TPA yang bersifat religius. Berbagai kegiatan pembiasaan yang bersifat religius tersebut digunakan untuk menumbuhkembangkan budaya hidup bersih dan sehat. Hal itu dilakukan sebagai upaya mewujudkan perintah Allah SWT di dalam QS. Al-Baqoroh ayat 222 dan Hadist Nabi Muhammad SAW tentang kebersihan merupakan sebagian dari iman. Kegiatan manajerial di TPA pun lebih difokuskan untuk membudayakan hidup bersih dan sehat. Ini dilakukan agar berbagai kegiatan pembiasaan religius untuk membudayakan hidup bersih dan sehat dapat berlangsung secara efektif dan efisien.

Berdasarkan hasil penelitian dapat diketahui bahwa ada empat kegiatan manajerial dalam pembudayaan hidup bersih dan sehat bagi anak usia dini di TPA RA Darussalam Kroya. Pertama, perencanaan kegiatan pembiasaan religius untuk menciptakan budaya hidup bersih dan sehat. Langkah awal yang dilakukan dalam kegiatan perencanaan adalah menetapkan tujuan kegiatan. Tujuan dari dilaksanakannya kegiatan pembiasaan religius untuk menciptakan budaya hidup bersih dan sehat adalah agar anak memiliki karakter cinta kebersihan dan mampu hidup dengan sehat. Saat ini mudah sekali ditemukan anak-anak usia dini yang sakit dikarenakan ia tidak bisa menjaga kebersihannya. Misalnya ketika ia makan lupa tidak mencuci tangan sehingga kotoran yang ada di tangan masuk ke tubuh anak dan menimbulkan penyakit. Misalnya lagi anak yang enggan memotong kukunya menjadikan kotoran yang ada di kuku terbawa ke badan saat makan dan mengakibatkan munculnya penyakit. Dari hasil dokumentasi dapat diketahui bahwa tujuan kegiatan pembiasaan religius untuk menciptakan budaya hidup bersih dan sehat memiliki relevansi dengan visi TPA RA Darussalam Kroya, yaitu membentuk generasi yang taqwa, kreatif, dan berakhlak mulia. Perilaku hidup bersih dan sehat merupakan wujud dari ketaqwaan anak, yaitu anak mematuhi perintah Allah SWT dan Rosulnya untuk menjaga kebersihan. Perilaku hidup bersih dan sehat juga merupakan salah satu bentuk akhlaqul karimah.

Berdasarkan tujuan yang telah ditetapkan kemudian pihak manajemen TPA RA Darussalam Kroya menetapkan berbagai kegiatan pembiasaan religius untuk membudayakan hidup bersih dan sehat. Kegiatan-kegiatan pembiasaan religius tersebut antara lain kegiatan memakai pakaian bersih, kegiatan makan siang, kegiatan sikat gigi, kegiatan berwudlu, kegiatan sholat dhuhur, kegiatan minum susu, kegiatan tidur siang dan merapikan peralatan tidur siang, kegiatan 
bermain dan merapikan peralatan bermain serta membersihkan area bermain, dan kegiatan thoharoh seperti BAK, BAB, dan mandi. Kemudian dibuat jadwal kegiatan untuk setiap kegiatan pembiasaan religius tersebut.

Berdasarkan kegiatan pembiasaan religius yang telah ditetapkan kemudian Kepala TPA RA Darussalam Kroya menginventarisir berbagai kebutuhan sarana dan prasarana yang dibutuhkan untuk melaksanakan kegiatan. Kegiatan inventarisir sarana dan prasarana harus dilakukan secara cermat. Kepala TPA RA Darussalam Kroya termasuk sangat cermat dalam melakukan inventarisir. la juga melakukan pemetaan skala prioritas terhadap sarana dan prasarana yang dibutuhkan. Skala prioritas tersebut nantinya dapat dijadikan sebagai pertimbangan dalam menentukan sarana atau prasarana mana yang lebih dahulu diadakan. Kemampuan Kepala TPA RA Darussalam Kroya yang demikian akan berimplikasi pada berlangsungnya pendayagunaan sarana dan prasarana secara optimal (Supiana, Hermawan, \& Hilmy, 2019).

Hasil inventarisir terhadap sarana dan prasarana yang dibutuhkan kemudian dituangkan dalam bentuk Rencana Anggaran Belanja (RAB) Kegiatan Pembiasaan. RAB tersebut kemudian diwujudkan dengan dana yang bersumber dari biaya pendidikan yang dibayarkan oleh wali murid. Diakui ataupun tidak ketersediaan anggaran pada suatu lembaga akan memberikan pengaruh yang signifikan terhadap pelaksanaan berbagai kegiatan pendidikan (Nurodin \& Minhajul K, 2019)

Penyusunan RAB kegiatan pembiasaan di TPA RA Darussalam Kroya dilakukan dengan melibatkan komite sekolah. Realisasi dari RAB juga dilakukan atas sepengetahuan komite sekolah. Demikian juga dengan pelaporannya, komite sekolah mengetahuinya. Hal itu berimplikasi pada terciptanya keterbukaan dalam penyelenggaraan kegiatan pembiasaan religius untuk membudayakan hidup bersih dan sehat pada anak. Keterbukaan tersebut membuat wali murid percaya bahwa pihak TPA RA Darussalam Kroya dapat mewujudkan harapan orangtua (Nurhidayah, 2019)

Kedua, pengorganisasian kegiatan pembiasaan religius untuk menciptakan budaya hidup bersih dan sehat. Langkah awal yang dilakukan pada pengorganisasian adalah menetapkan guru sebagai personel dalam kegiatan pembiasaan religius untuk menciptakan budaya hidup bersih dan sehat. Hasil penetapan kemudian dijadikan sebagai bahan untuk membuat petugas piket kegiatan pembiasaan. Guru sebagai petugas piket diberi tugas untuk menjadi penanggungjawab dalam setiap kegiatan pembiasaan religius. Kemudian kepala TPA RA Darussalam Kroya melakukan koordinasi dengan guru untuk membicarakan berbagai hal yang berhubungan dengan pelaksanaan kegiatan pembiasaan religius untuk menciptakan budaya hidup bersih dan sehat. Pada pengorganisasian dilakukan pula kegiatan sosialisasi dengan wali murid terkait dengan kegiatan pembiasaan religius untuk menciptakan budaya hidup bersih dan sehat baik dari sisi rencana kegiatannya, pelaksanaan kegiatannya dan hasil kegiatannya.

Kegiatan pengorganisasian pada dasarnya ditujukan agar setiap stakeholders yang terlibat pada pembudayaan hidup bersih dan sehat dapat terlibat aktif di dalam pelaksanaannya. Dalam konteks keorganisasian, keterlibatan berbagai pihak dalam bekerja akan menjadi faktor determinan dalam kemajuan pada suatu organisasi. Keterlibatan tersebut ditunjukkan oleh 
penggunaan waktu, tenaga dan pikiran secara maksimal di setiap kegiatan. Keterlibatan setiap stakeholders akan memberikan kontribusi tingginya tingkat ketidakhadiran dan meningkatkan produktivitas kerja serta loyalitasnya (Patras \& Hidayat, 2019). Stakeholders yang paling utama pada program pembudayaan hidup bersih dan sehat adalah para guru.

Ketiga, pelaksanaan kegiatan pembiasaan religius untuk menciptakan budaya hidup bersih dan sehat. Berdasarkan hasil observasi dapat diketahui bahwa anak setelah selesai berlajar di RA pada jam 10.30 didampingi guru kelas untuk mengganti pakaian seragam dengan pakaian bebas yang sudah dibawakan oleh orangtuanya dari rumah. Setelah itu anak diberi kesempatan untuk bermain bersama. Pada jam 11.00 anak melakukan kegiatan makan siang. Rangkaian kegiatan makan siang ini meliputi cuci tangan sebelum makan, berdoa sebelum makan, makan dengan tangan kanan, saling berbagi makanan, berdoa setelah makan, cuci tangan setelah makan serta anak mencuci dan merapikan peralatan makannya. Anak-anak pada saat makan duduk melingkar secara berkelompok. Mereka didampingi oleh guru dan dibimbing oleh guru agar bisa makan dengan tertib dan sesuai dengan adab Islam.

Anak-anak pada jam 11.30 setelah selesai makan siang didampingi serta dibimbing oleh guru untuk menggosok gigi dan berwudlu. Kegiatan ini dilakukan secara bergiliran. Guru juga memberikan pendampingan dan bimbingan kepada anak tentang tata cara menggosok gigi dan berwudlu. Sesampainya di masjid anak-anak diarahkan guru menuju masjid. Anak laki-laki diarahkan untuk memakai sarung, dan anak perempuan di arahkan memakai mukena di masjid. Sambil menunggu adzan dhuhur anak-anak diarahkan untuk bersholawat lalu dilanjutkan sholat dhuhur. Setelah selesai sholat dhuhur dilanjutkan kegiatan murojaah hingga jam 12.30. Selesai murojaah anak diminta merapikan sarung, mukena dan sajadah yang dikenakannya.

Pada jam 12.30 (menjelang tidur siang) guru memberi kesempatan kepada anak-anak untuk minum susu dan buang air terlebih dahulu. Setelah itu mereka mendengarkan cerita-cerita islami dari guru. Kegiatan bercerita dapat dijadikan sebagai salah satu strategi untuk menginternalisasikan nilai-nilai karakter seperti cinta kebersihan. Anak pun akan sangat tertarik dengan berbagai cerita yang disampaikan oleh guru karena di usia dini anak memiliki rasa ingin tahu yang tinggi (Juanda, 2019). Setelah kegiatan bercerita selesai, guru membimbing anak-anak untuk berdo'a sebelum tidur. Kemudian tidur. Waktu tidur anak-anak maksimal sampai jam 14.00. Guru akan membangunkan anak jika ia tidur melebihi batas maksimal. Bangun tidur mereka diarahkan untuk duduk sebentar dan cuci muka. Anak-anak juga diberi kesempatan bermain sebentar lalu mulai mengantri untuk mandi. Guru mengarahkan anak-anak untuk berwudlu setelah selesai mandi. Kemudian guru mendampingi anak-anak untuk berpakaian dan menata tas mereka. Pada jam 15.00 anak-anak sudah siap dijemput oleh orangtuanya.

Kegiatan pembiasaan untuk membudayakan hidup bersih dan sehat lebih bersifat religius. Anak dibiasakan thoharoh melakukan praktik cuci tangan, buang air kecil dan buang air besar, berwudlu dan mandi. Anak dibiasakan untuk membersihkan peralatan makan setelah melakukan doa sesudah makan, anak dibiasakan merapikan peralatan tidurnya dan membersihkan lantai setelah berdoa bangun tidur, dan lainnya. Para guru meyakini bahwa pembiasaan 
religius akan lebih efektif digunakan untuk membudayakan hidup bersih dan sehat. Keyakinan tersebut sesuai dengan hasil penelitian Rahayu dan Munadi. Hasil penelitiannya menunjukkan bahwa pada dasarnya kebiasaan anak untuk berperilaku positif (termasuk dalam menjaga kebersihan dan kesehatan diri) sangat dipengaruhi oleh religiusitas anak (Munadi \& Rahayu, 2019)

Anak-anak sangat percaya diri ketika mengikuti berbagai kegiatan di atas. Anak-anak berkomunikasi dengan ustadzahnya tanpa ada rasa canggung. Anakanak berani mengutarakan pertanyaan tentang berbagai hal yang dijelaskan dan dicontohkan oleh guru saat melaksanakan kegiatan pembiasaan religius untuk membudayakan hidup bersih dan sehat. Hal itu terjadi karena adanya komunikasi dua arah antara guru dan anak serta adanya kenyamanan yang dirasakan oleh anak dengan perlakuan guru terhadapnya. Hal yg menarik adalah saat mereka saling mengingatkan antar teman untuk konsisten dalam melaksanakan kegiatan pembiasan religius sesuai dengan aturan dan instruksi dari guru. Kegiatan yang dilakukan oleh anak-anak dapat terorganisir dengan baik. Ini berarti guru di TPA RA Darussalam Kroya sudah memiliki kemampuan dalam mengelola peserta didik (Jahari dkk., 2019)

Guru memberikan reward kepada anak-anak yang konsisten berperilaku sesuai dengan aturan dan instruksi ketika melaksanakan kegiatan pembiasan religius. Reward tersebut berupa pemberian pujian dan pemberian simbol bintang yang dilekatkan di dadanya. Upaya tersebut bisa memotivasi anak untuk konsisten dalam berbuat kebaikan. Jika ada anak yang berperilaku tidak sesuai dengan aturan dan instruksi guru maka ia akan ditegur dan diberi nasehat oleh guru. Jika teguran itu masih juga belum diindahkan oleh anak maka guru akan memberikan pendampingan khusus pada anak.

Guru juga ikut melakukan pembiasaan religius untuk membudayakan hidup bersih dan sehat. Tujuannya adalah untuk memberikan deskripsi secara langsung tentang bagaimana cara menjaga kebersihan dan cara hidup sehat. Ini karena anak usia dini lebih banyak belajar dengan cara melakukan imitasi. Saat bersama melakukan aktivitas pembiasaan guru juga secara spontanitas memberikan teguran kepada anak yang belum mampu menjaga kebersihan. Guru juga secara spontan memberikan pujian kepada anak yang mampu menjaga kebersihan. Misal ketika sedang makan bersama anak, kalau ada nasi anak bercecer kemudian guru bilang "ambil, letakkan di sini (sambil menunjuk plastik sampah). Guru juga ikut merapikan peralatan makan sambil menegur anak dengan teguran "lihat, ada sampah yg tercecer tidak?". Kemudian anakanak akan menjawab sesuai dengan apa yg mereka lihat dan perhatikan. Jika ditemukan sampah maka anak diminta untuk membuangnya dan menyapu lantai yang kotor karena sampah.

Menjelang anak-anak dijemput oleh orangtuanya para guru selalu menyisipkan pesan pada anak-anak untuk selalu patuh pada orangtua, tetap mengaji dan sholat lima waktu, serta tetap menjaga kebersihan diri dan kebersihan lingkungan. Penjelasan tersebut intens dilakukan karena guru yakin ketika pesan itu terus menerus disampaikan maka anak akan terus mengingatnya.

Berbagai sarana yang digunakan dalam kegiatan pembiasaan religius untuk membudayakan hidup sehat dan bersih antara lain 4 matras besar dan 1 matras kecil, 12 bantal, peralatan makan seperti piring, sendok dan magicom, 
peralatan mandi lengkap (sabun, shampo, dan sikat gigi), peralatan sholat, dispencer, buku cerita dan Iqro serta Juz Amma. Sedangkan prasarana yang digunakan antara lain ruang kamar, kamar mandi, westafel, masjid, halaman sekolah, dan ruang kelas. Keberadaan sarana dan prasarana yang memadai pada suatu lembaga pendidikan dapat menghasilkan kegiatan pendidikan, termasuk kegiatan pembudayaan hidup sehat dan bersih secara efektif. Efektivitas tersebut didapat karena setiap kegiatan bisa dilakukan dengan lebih mudah dan lancar ketika ada berbagai peralatan pendukungnya (Sinta, 2019).

Kepala TPA RA Darussalam Kroya sebagai pemimpin ikut terlibat secara intens dalam pelaksanaan kegiatan pembiasaan religius untuk membudayakan hidup bersih dan sehat. la di dalam melaksanakan tugasnya dibantu oleh salah satu guru yang ditugasinya sebagai penanggungjawab (PJ) TPA. Kepala TPA RA Darussalam Kroya juga diberi jadwal piket TPA sama seperti guru lainnya. Kesediaan dan keterlibatan Kepala TPA RA Darussalam Kroya untuk menjadi guru piket TPA memberikan nilai tambahan terhadap kelancaran pelaksanaan kegiatan. Nilai tambahannya yaitu Kepala TPA RA Darussalam Kroya benarbenar senantiasa memastikan bahwa sarana yang dibutuhkan pada setiap kegiatan slalu ada, keterlibatan Kepala TPA RA Darussalam Kroya memunculkan motivasi pada diri guru agar mereka bisa bekerja dengan lebih baik lagi, dan keteladanan dari seorang pemimpin telah menciptakan iklim kerja yang kondusif (Aguswara \& Rachmadtullah, 2017).

Berdasarkan hasil observasi juga dapat diketahui bahwa komunikasi antara Kepala TPA RA Darussalam Kroya dengan guru berlangsung dua arah. Mereka saling sharing, saling memotivasi, saling memberikan masukan, dan saling bekerjasama dalam melaksanakan kegiatan pembiasaan untuk membudayakan hidup bersih dan sehat. Hal itu bisa dilakukan oleh Kepala TPA RA Darussalam Kroya karena ia memimpin lembaganya dengan gaya kepemimpinan demokratis. Kepemimpinan demokratis dapat menjadikan kinerja guru meningkat dan partisipasi belajar anak optimal. Kedua hal tersebut dapat menjadikan jalannya suatu program, termasuk program pembudayaan hidup bersih dan sehat berlangsung optimal sehingga tujuan program dapat tercapai (Setyaningsih, 2019)

Keempat, pengawasan kegiatan pembiasaan religius untuk menciptakan budaya hidup bersih dan sehat. Pengawasan pada dasarnya dilakukan sebagai upaya untuk mengontrol jalannya pelaksanaan suatu kegiatan, termasuk kegiatan pembiasaan religius untuk menciptakan hidup sehat dan bersih (Muhtifah dkk., 2019). Kegiatan pengawasan yang dilakukan oleh Kepala TPA RA Darussalam Kroya dilakukan dengan melakukan kegiatan monitoring terhadap pelaksanaan kegiatan pembiasaan religius untuk membudayakan hidup bersih dan sehat. Objek monitoringnya yaitu kinerja guru, tampilan perilaku anak, serta penggunaan sarana dan prasarana.

Monitoring terhadap kinerja guru dilakukan secara insidental oleh Kepala TPA RA Darussalam Kroya. Aspek-aspek yang dimonitoring antara lain kemampuan guru dalam memimpin dan membina anak, kemampuan guru dalam memberikan teladan pada anak untuk hidup bersih dan sehat, serta kemampuan guru untuk menjalin relasi dengan anak, orangtua dan rekan sejawatnya. Hasil monitoring dicatat pada buku kerja Kepala TPA RA Darussalam Kroya. Hasil monitoring disampaikan setiap satu bulan sekali pada kegiatan rapat evaluasi 
kinerja guru. Hasil rapat evaluasi kemudian dijadikan sebagai bahan masukan oleh guru sebagai upaya memperbaiki kinerjanya. Kegiatan monitoring yang dilakukan oleh pimpinan, termasuk Kepala TPA RA Darussalam Kroya dapat memberikan kontribusi terhadap terciptanya disiplin kerja para guru (Wijaya, 2019).

Kemudian kegiatan monitoring terhadap tampilan perilaku anak dilakukan oleh Kepala TPA RA Darussalam Kroya dan PJ TPA. Pada kegiatan ini didiagnosa perilaku anak yang bisa menjadi faktor penghambat dalam pelaksanaan kegiatan pembiasaan untuk membudayakan hidup bersih dan sehat. Perilaku anak yang bisa menjadi faktor penghambat seperti anak yang susah dikondisikan untuk mengikuti suatu kegiatan, anak yang mau melakukan kegiatan jika didampingi oleh guru tertentu, anak yang berperilaku agresif, anak yang suka bertengkar, dan anak yang masih berperilaku manja.

Sementara itu monitoring terhadap penggunaan sarana dan prasarana dilakukan dengan mengecek keadaan sarana dan prasarana, misalnya mengecek ketersediaan air, mengecek ketersediaan nasi dan sayuran, mengecek kebersihan kamar mandi, mengecek kerapian rak lemari anak, mengecek keadaan alat-alat bermain, mengecek kerapian kamar tidur anak, mengecek kerapihan rak piring, mengecek kebersihan ruang makan, mengecek kebersihan dapur, dan lain sebagainya.

Kegiatan monitoring terhadap perilaku anak dilakukan pula oleh guru. hal itu dilakukan untuk mendiagnosa masalah yang dihadapi oleh anak saat mengikuti kegiatan pembiasaan untuk membudayakan hidup bersih dan sehat. Masalah utama yang menjadi penghambat anak untuk membudayakan hidup bersih dan sehat adalah kemanjaan. Kemanjaan tersebut menjadikan anak kurang mandiri. Kekurang-mandirian pada anak menjadikan kemampuannya untuk menjagar kebersihan diri dan lingkungannya lemah. Anak yang manja juga ditengarai memiliki keadaan fisik yang lemah sehingga rentan sakit. Untuk mengatasi masalah tersebut guru melakukan pendampingan khusus dan mengajak orang tua untuk bekerjasama dalam mengatasinya. Jika orangtua belum maksimal bekerjasama karena direpotkan oleh urusan pekerjaannya maka guru akan mengadakan kerjasama dengan pihak lain, seperti dengan kakak, kakek, dan nenek. Kemanjaan pada diri anak selain bisa menimbulkan ketidakmandirian juga dapat menjadikan self regulation pada anak lemah (Pangestuti dkk., 2019) Dalam konteks pembudayaan hidup bersih dan sehat, lemahnya self regulation pada anak bisa menjadikan anak malas hidup bersih dan kurang mampu menjaga kesehatannya.

Perkembangan atau progress kemampuan anak dalam menjaga kebersihan dan hidup sehat dilaporkan oleh guru kepada orangtua secara berkala pada pertemuan-pertemuan formal dan melalui media komunikasi seperti what's up. Selain itu untuk mengetahui perkembangan kemampuan anak dalam menjaga kebersihan dan hidup sehat di lingkungan keluarga, guru memberikan buku penghubung kepada orangtua. Buku penghubung tersebut berisi berbagai kegiataan yang harus dilakukan oleh anak di lingkungan keluarga agar lingkungan keluarganya tetap bersih dan sehat. Setiap satu minggu sekali guru menarik buku penghubung rersebut kemudian direview dan anak diberi feedback berdasarkan hasil review. Jadi buku penghubung memiliki fungsi sebagai media pengontrol perilaku anak di lingkungan keluarga. Pencapaian hasil dari 
pembudayaan hidup bersih dan sehat akan lebih optimal jika kegiatan pembiasaan religius bukan hanya dilaksanakan di lembaga PAUD tetapi juga dilaksanakan di lingkungan keluargan (Sesmiarni, 2019)

\section{SIMPULAN}

Berdasarkan hasil penelitian dapat disimpulkan bahwa kegiatan manajerial dalam pembudayaan hidup bersih di TPA RA Darussalam Kroya dilakuan melalui empat tahapan. Pertama, perencanaan kegiatan pembiasaan religius untuk menciptakan budaya hidup bersih dan sehat. Pada tahap ini ditetapkan tujuan kegiatan pembiasaan religius, menetapkan jenis-jenis kegiatan pembiasaan religius, membuat jadwal kegiatan pembiasan religius, menginventarisir berbagai kebutuhan sarana dan prasarana yang dibutuhkan, membuat dan mengaktualisasikan $\mathrm{RAB}$ kegiatan pembiasan religius untuk menciptakan budaya hidup bersih dan sehat.

Kedua, pengorganisasian kegiatan pembiasaan religius untuk menciptakan budaya hidup bersih dan sehat. Pada tahap ini dilakukan penetapan guru sebagai personel dalam kegiatan pembiasaan religius, membuat petugas piket kegiatan pembiasaan, melakukan koordinasi dengan guru untuk membicarakan berbagai hal yang berhubungan dengan pelaksanaan kegiatan pembiasaan religius, dan melakukan sosialisasi kegiatan pembiasaan religius untuk menciptakan budaya hidup bersih dan sehat.

Ketiga, pelaksanaan kegiatan pembiasaan religius untuk menciptakan budaya hidup bersih dan sehat. Kegiatan pembiasaan religius dapat berlangsung efisien karena dilaksanakan sesuai dengan jadwal yang telah ditetapkan. Kegiatan pembiasaan religius dapat berlangsung efektif karena ketersediaan sarana dan prasarana serta kemampuan guru dalam mengelola anak-anak.

Keempat, pengawasan kegiatan pembiasaan religius untuk menciptakan budaya hidup bersih dan sehat. Kegiatan pengawasan yang dilakukan oleh kepala TPA RA Darussalam Kroya dilakukan dengan melakukan kegiatan monitoring terhadap pelaksanaan kegiatan pembiasaan religius untuk membudayakan hidup bersih dan sehat. Objek monitoringnya yaitu kinerja guru, tampilan perilaku anak, serta penggunaan sarana dan prasarana.

\section{REFERENSI}

Aguswara, W. W., \& Rachmadtullah, R. (2017). Pengaruh Gaya Kepemimpinan Kepala Sekolah dan Iklim Organisasi dengan Kinerja Guru Pendidikan Anak Usia Dini. JPUD - Jurnal Pendidikan Usia Dini, 11(2), 369-385. https://doi.org/10.21009/JPUD.112.14

Ana, N., Ali, M., \& Yuniarni, D. (2016). Pembiasaan Perilaku Hidup Bersih Anak Usia Dini di PAUD Melati Jaya Jungkat Kecamatan Siantan. Jurnal Pendidikan dan Pembelajaran Khatulistiwa, 5(10). http://jurnal.untan.ac.id/index.php/jpdpb/article/view/17008

Erfantini, I. H., Mulyoto, G. P., \& Fitriah, N. (2019). Bimbingan Kelompok Teknik Modeling Untuk Meningkatkan Percaya Diri Pada Anak Usia Dini. Preschool: Jurnal Perkembangan dan Pendidikan Anak Usia Dini, 1(1), 43-52. http://dx.doi.org/10.18860/preschool.v1i1.8175 
Farhani, D. (2019). MANAJEMEN PENDIDIKAN KARAKTER MELALUI KEGIATAN KOKURIKULER KEAGAMAAN. Jurnal Isema: Islamic Educational Management, 209-220. https://doi.org/10.15575/isema.v4i2.5619

Iswantiningtyas, V., \& Wulansari, W. (2018). Pengembangan Model Penilaian Pendidikan Karakter Aanak Usia Dini. JPUD - Jurnal Pendidikan Usia Dini, 12(2), 361-370. https://doi.org/10.21009/JPUD.122.17

Jahari, J., Khoiruddin, H., \& Nurjanah, H. (2019). Manajemen Peserta Didik. Jurnal Isema: Islamic Educational Management, 3(2), 53-63. https://doi.org/10.15575/isema.v3i2.5009

Juanda, J. (2019). Pendidikan Karakter Anak Usia Dini melalui Sastra Klasik Fabel Versi Daring. Jurnal Obsesi : Jurnal Pendidikan Anak Usia Dini, 3(1), 39. https://doi.org/10.31004/obsesi.v3i1.126

Margowati, S., \& Astuti, F. P. (2017). Implementasi PHBS Pada Anak Usia Dini Melalui Metode Seling. Journal of Holistic Nursing Science, 4(1), 1-6.

Moleong, L. J. (2018). Metodologi Penelitian Kualitatif. PT Remaja Rosdakarya.

Muhtifah, L., Hendry, E., Rahmatullah, M., \& Suhardiman, S. (2019). Survei Kepuasan Mahasiswa Dan Dosen Terhadap Kualitas Pelayanan Pendidikan Dengan Pendekatan Servqual Di Ftik lain Pontianak Tahun 2018. Jurnal Isema: Islamic Educational Management, 4(1), 105-118. https://doi.org/10.15575/isema.v4i1.5296

Mukhlis, A., \& Mbelo, F. H. (2019). Analisis Perkembangan Sosial Emosional Anak Usia Dini Pada Permainan Tradisional. Preschool: Jurnal Perkembangan dan Pendidikan Anak Usia Dini, 1(1), 11-28. http://dx.doi.org/10.18860/preschool.v1i1.8172

Mulyasa, E. (2017). Strategi Pembelajaran PAUD. PT Remaja Rosdakarya.

Munadi, M., \& Rahayu, W. (2019). Inculcation Religiosity in Preschoolers Local content curriculum. JPUD - Jurnal Pendidikan Usia Dini, 13(2), 201-216. https://doi.org/10.21009/JPUD.132.01

Nurhidayah, N. (2019). Penganggaran Keuangan Madrasah. Jurnal Isema: Islamic Educational Management, 4(1), 133-146. https://doi.org/10.15575/isema.v4i1.5646

Nurodin, A., \& Minhajul K, I. (2019). Implikasi Peran Manajemen Pembiayaan Madrasah Terhadap Kegiatan Ekstrakulikuler Keagamaan MTs. AsSawiyah Kabupaten Bandung. Jurnal Isema: Islamic Educational Management, 4(2), 267-276. https://doi.org/10.15575/isema.v4i2.5566

Pamungkas, J., Syamsudin, A., \& Harun, H. (2018). Gamelan Bocah (GACAH): Penumbuhan Karakter Kebangsaan di TK Sari Asih Yogyakarta. ALATHFAL: Jurnal Pendidikan Anak, 4(2), 199-210. https://doi.org/10.14421/al-athfal.2018.42-07

Pangestuti, R., Kadiyono, A. L., Cahyadi, S., \& Agustiani, H. (2019). A Modifying the Instrument of Self-Regulation in Early Childhood Assessment. JPUD Jurnal Pendidikan Usia Dini, 13(1), 114-127. https://doi.org/10.21009/10.21009/JPUD.131.09

Patras, Y. E., \& Hidayat, R. (2019). Pengaruh Kepemimpinan, Keadilan, dan Kepercayaan pada Keterlibatan Kinerja Dosen. MANAGERIA: Jurnal Manajemen Pendidikan Islam, 4(1), 85-101. https://doi.org/10.14421/manageria.2019.41-06 
Prahesti, S. I., Taulany, H., \& Fauziah, S. (2019). Media Compact Disk Interaktif Berbudaya Sehat untuk Meningkatkan Kosa Kata Anak Usia Dini. Jurnal Obsesi: Jurnal Pendidikan Anak Usia Dini, 3(2), 377. https://doi.org/10.31004/obsesi.v3i2.149

Prayoga, A. (2019). Manajemen Program Pembinaan Akhlak Karimah Peserta Didik Melalui Ekstrakulikuler. Jurnal Isema: Islamic Educational Management, 4(1), 93-104. https://doi.org/10.15575/isema.v4i1.5142

Rahmawati, M. C., \& Dewi, N. D. L. (2019). Instilling Clean and Healthy Life Behavior in Paud Atmabrata, Cilincing, Jakarta. MITRA: Jurnal Pemberdayaan Masyarakat, 3(1), 41-49. https://doi.org/10.25170/mitra.v3i1.499

Saajidah, L. (2019). Fungsi-Fungsi Manajemen Dalam Pengelolaan Kurikulum. Jurnal Isema: Islamic Educational Management, 3(2), 84-91. https://doi.org/10.15575/isema.v3i2.5012

Santoso, S. T. P., \& Sutama, I. W. (2019). Profil Kemampuan Asertif Pada Usia Pra Sekolah. Preschool: Jurnal Perkembangan dan Pendidikan Anak Usia Dini, 1(1), 29-42. http://dx.doi.org/10.18860/preschool.v1i1.8173

Sesmiarni, Z. (2019). The Effective Moral Education on Early Childhood As an Effort Against Immoral Culture. Jurnal Obsesi : Jurnal Pendidikan Anak Usia Dini, 3(2), 561. https://doi.org/10.31004/obsesi.v3i2.191

Setyaningsih, K. (2019). Democratic Leadership: Upaya Kepala Sekolah dalam Membangun Kualitas Peserta Didik di Sekolah Dasar (SD) Tunas Teladan Palembang. MANAGERIA: Jurnal Manajemen Pendidikan Islam, 4(1), 118. https://doi.org/10.14421/manageria.2019.41-01

Sinta, I. M. (2019). Manajemen Sarana dan Prasarana. Jurnal Isema: Islamic Educational Management, 4(1), 77-92. https://doi.org/10.15575/isema.v4i1.5645

Sugiyono. (2015). Metode Penelitian (Kuantitatif, Kualitatif dan R\&D). Alfabeta.

Sulastri, S., \& Fahmi. (2019). Peningkatan Karakter Jujur Melalui Kegiatan Role Play pada Anak di TK Aisyiah 4 Beringin Sakti Pagar Alam Selatan. ALATHFAL: JURNAL PENDIDIKAN ANAK, 5(1), 69-82. https://doi.org/10.14421/al-athfal.2019.51-05

Supiana, S., Hermawan, A. H., \& Hilmy, M. F. (2019). Manajemen Sarana Dan Prasarana Diniyah Takmiliyah. Jurnal Isema: Islamic Educational Management, 3(2), 23-41. https://doi.org/10.15575/isema.v3i2.5007

Supiana, S., Hermawan, A. H., \& Wahyuni, A. (2019). Manajemen Peningkatan Karakter Disiplin Pesera Didik Melalui Kegiatan Ekstrakulikuler. Jurnal Isema: Islamic Educational Management, 4(2), 193-208. https://doi.org/10.15575/isema.v4i2.5526

Tanto, O. D., Hapidin, H., \& Supena, A. (2019). Penanaman Karakter Anak Usia Dini dalam Kesenian Tradisional Tatah Sungging. Jurnal Obsesi : Jurnal $\begin{array}{llll}\text { Pendidikan Anak Usia } & 337 .\end{array}$ https://doi.org/10.31004/obsesi.v3i2.192

Wijaya, C. (2019). Supervisi Manajerial Kepala Madrasah Dalam Meningkatkan Kedisiplinan Kerja Guru. Jurnal Isema : Islamic Educational Management, 4(1), 65-76. https://doi.org/10.15575/isema.v4i1.5294 
Novan Ardy Wiyani

Wulandari, H. (2011). Pelaksanaan Pendidikan Kesehatan Perilaku Hidup Bersih dan Sehat Pada Anak Usia Dini di TK ABA Tegalsari Yogyakarta. UIN Sunan Kalijaga.

Yufiarti, Y., Edwita, \& Suharti. (2019). Health Promotion Program (JUMSIH); To Enhance Children's Clean and Healthy Living Knowledge. JPUD - Jurnal Pendidikan Usia Dini, 13(2), 341-355. https://doi.org/10.21009/JPUD.132.10 